\title{
Edukasi kesehatan pencegahan Covid-19 kepada masyarakat tepian Sungai Kuantan
}

\section{Suyanto ${ }^{*}$, \& Zulkarnaini}

Universitas Riau

*suyantounri@gmail.com

\begin{abstract}
Abstrak. Saat ini penyakit Covid-19 telah menginfeksi masyarakat tidak hanya di wilayah perkotaan tapi juga pedesaan. Upaya pencegahan telah dilakukan secara massive oleh berbagai pihak berupa pesan kesehatan, namun penyampaian pesan tersebut belum dapat menyentuh bagi masyarakat yang tinggal jauh dari ibukota. Untuk itu kami dari ademisi Universitas Riau bersama mahasiwa kukerta melakukan upaya sosialiasi penegahan mengenai peyakit Covid-19 kepada masyarakat Desa Pulau Kedundung yang tinggal di pinggiran sungai Kuantan. Adapun kegiatan yang dilakukan adalah berupa sosialiasi protocol kesehatan berupa penggunaan masker dan mencuci tangan teratur dan penegnalan gejala penyakit Covid-19. Hasil dari kegiatan ini diharapakan dapat menambah pemahaman masyarakat tentang pengendalian Covid-19 dan merupakan upaya nyata dalam melakukan pencegahan penyebaran penyakit ini di masyarakat.
\end{abstract}

Kata kunci: Covid-19, Sungai Kuantan, edukasi kesehatan, pencegahan penyakit

Abstract. Covid-19 has infected people not only in urban areas but also in rural areas. Prevention efforts have been carried out massively by various parties in the form of health messages, but the delivery of these messages has not been able to touch people who live far from the capital. For this reason, there should be an effort to socialize the prevention of Covid-19 diseases, such as for people living on the banks of the Kuantan River. The activity carried out by academics at the University of Riau together with Kukerta students is a real effort to prevent the spread of this disease in the community.

Keywords: Covid-19, Kuantan River, health education, disease control

To cite this article: Suyanto., \& Zulkarnaini. 2020. Edukasi kesehatan pencegahan Covid-19 kepada masyarakat tepian Sungai Kuantan. Unri Conference Series: Community Engagement 2: 281-285.

https://doi.org/10.31258/unricsce.2.281-285

(C) 2020 Authors

Peer-review under responsibility of the organizing committee of Seminar Nasional Pemberdayaan Masyarakat 2020 


\section{PENDAHULUAN}

Corona virus disease-2019 (Covid-19) merupakan penyakit yang disebabkan oleh infeksi Coronvirus yang pertama kali di isolasi dari saluran pernapasan bawah pasien di Wuhan(Byass, 2020). Saat ini telah dikonfirmasi bahwa virus tersebut mampu menular dari manusia ke manusia.(Pan et al., 2020) Sebagian besar pasien terkonfirmasi mengalami penyakit pernapasan ringan hingga sedang dan sembuh tanpa memerlukan perawatan khusus. Namun orang dengan usia tua atau orang yang memiliki masalah medis mendasar seperti penyakit kardiovaskular, diabetes, penyakit pernapasan kronis, dan kanker mungkin akan menunjukkan gejala yang lebih serius.(Djalante et al., 2020) Virus Corona menyebar terutama melalui tetesan air liur atau keluar dari hidung ketika orang yang terinfeksi batuk atau bersin. (Tan, 2005)

Indonesia merupakan salah satu negara yang terdampak parah dari infeksi Covid ini. (DAF, 2020) Tampa upaya pencehagan optimal, maka penyakit ini akan tidak terkendali.(Sasmita et al., 2020) Data dari Dinas Kesehatan Riau menunjukan hampir seluruh kabupaten di Riau telah terinfeksi penyakit Covid-19.(Riau Tanggap Virus Corona | Pemprov Riau, 2020) Bahkan masyarakat desa yang jauh dari perkotaan pun telah terjangkit. Boleh dikatakan tidak ada daerah yang aman dari penyakit ini. Pemerintah telah melakukan upaya sosialiasi pencegahan kepada masyarakat baik berupa informasi melalui media elektronik maupun penyampaian secara langsung ke masyarakat, namun dikarenakan keterbatasan sumber daya, upaya ini seringkali hanya dilakukan di wilayah perkotaan dan daerah yang ramai penduduknya. (Djalante et al., 2020)

Sungai merupakan nadi kehidupan bagi masyarakat Riau. Banyak masyarakat yang tinggal di pinggiran sungai dan jauh dari perkotaan. Masyarakat yang hidup dan tinggal sepanjang aliran sungai telah memberikan warna dan ciri khas terhadap perkembangan budaya dan pola pikir masyarakat.(Riau - Wikipedia bahasa Indonesia, ensiklopedia bebas, 2020) . Untuk itu kami dari ademisi Universitas Riau bersama mahasiwa kukerta melakukan upaya sosialiasi penegahan mengenai peyakit Covid-19 kepada masyarakat Desa Pulau Kedundung yang tinggal di pinggiran sungai Kuantan. Adapun kegiatan yang dilakukan adalah berupa sosialiasi protocol kesehatan berupa penggunaan masker dan mencuci tangan teratur dan penegnalan gejala penyakit Covid-19. Melalui kegiatan ini diharapakan dapat meningkatkan pemahaman akan pencegahan penyakit merupakan salah satu solusi yang dapat dilakukan dalam mengurangi kerentanan masyakat(Maryanti and Lestari, 2020) terhadap penyakit seperti yang kami lakukan kepada masyarakat Desa Pulau Kedungdung, Kecamatan Kuantan Tengah, Kabuapten Kuantan Singigi.

\section{METODE PENERAPAN}

Kegiatan edukasi umunya dilakukan melalui ceramah dengan menggunakan media presentasi (Sampurna, 2020) Bentuk kegiatan yang kami lakukan adalah penyuluhan kepada masyarakat yang tinggal desa Pulau Kedungdung di pinggiran sungai Kuantan. Kegiatan ini dilakukan dengan melaksanakan program pendidikan dan promosi kesehatan secara berkelanjutan bersama mahasiswa Kukerta Balek Kampung.

Dalam melakukan kegiatan ini, beberapa tahapan dilakukan seperti melakukan pendekatan dengan Puskesmas Teluk Kuantan dan Kepala Desa Pulau Kedungdung. Deas ini dipilih karena merupakan salah satu desa yang menjadi mitra Puskesmas pada bulan tersebut. Selain itu juga terdapat mahasisws Kukerta sehingga memydhakan kami dalam melakukan koordinasi untuk menentukan jadwal pelaksanaan penyuluhan kepada para kader serta masyarakat.

Sekitar satu minggu sebelum kegiatan, mahasiswa kukerta melakukan sosialaisi kegitaan dan mengundang peserta hadir ke kantor desa. Jumlah masyarakat yang datang disesuaikan dengan kapasitas ruangan agar protocol kesehatan tetap terlaksana seperti mencuci tangan dan mengukur temperature tubuh (Gambar 1) sebelum memasuki ruangan, menjaga jarak aman antar peserta, menggunakan masker dan membatasi waktu pemyuluhan dalam ruangan kurang dari 45 menit. 


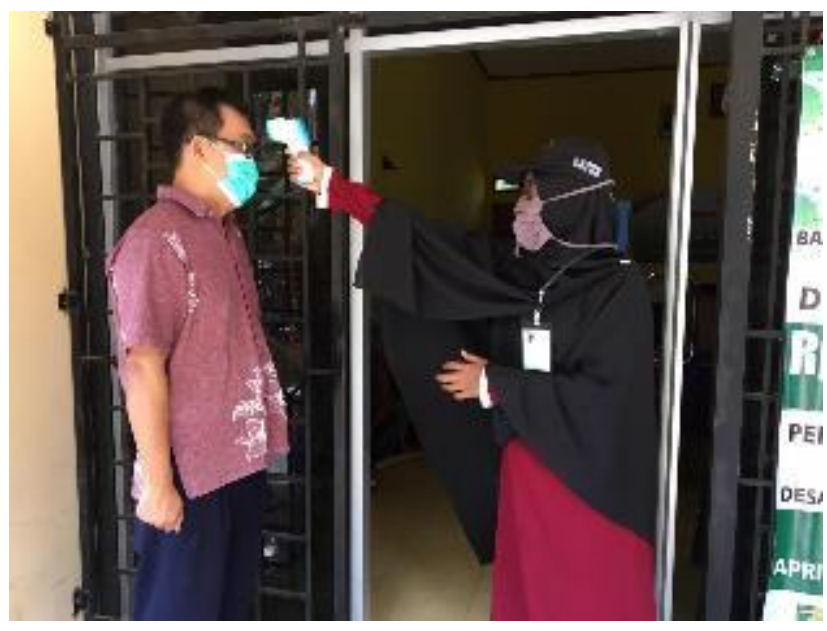

Gambar 1. Mahasiswa Kukerta melakukan pengukuran temperature kepada semua yang memasuki ruangan

\section{HASIL DAN KETERCAPAIAN}

Masyarakat desa Pulau Kedundung berada jauh dari hiruk pikuk keramaian. Desa Pulau Kedundung terletak 4 Km dari pusat kota sehingga masyarakatnya banyak yang berprofesi sebagai petani dan pengembala. Keadaan ekonomi di desa Pulau Kedundung terkategori rendah. Hal ini yang menyebabkan tingkat pendidikan di desa rendah, kebanyakan hanya sampai SMA. Banyak pemuda desa yang tidak melanjutkan ke perguruan tinggi, hal ini disebabkan karna keadaan ekonomi yang tidak mendukung.

Saat kegiatan edukasi ini dilakukan, status keaadaan Covid-19 di kabuapten Kauantan Singingi adalah zona merah, namun kasus umumnya masih berada di ibukota kabupaten. Belum ditemukan kasus di desa Pulau Kedungdung, namun mengingat adanya kemungkina pergerakan penduduk dari desa ke kota, maka setiap saat penemuan kasus dapat saja terjadi. Melihat siatuasi diatas, maka disusun solusi pegembangan masyarakat yaitu dengan mengadakan edukasi pencegahan Covid-19 kepada Masyarakat dan Kader Posbindu desa Pulau Kedungdung, Taluk Kuantan (Gambar 2).

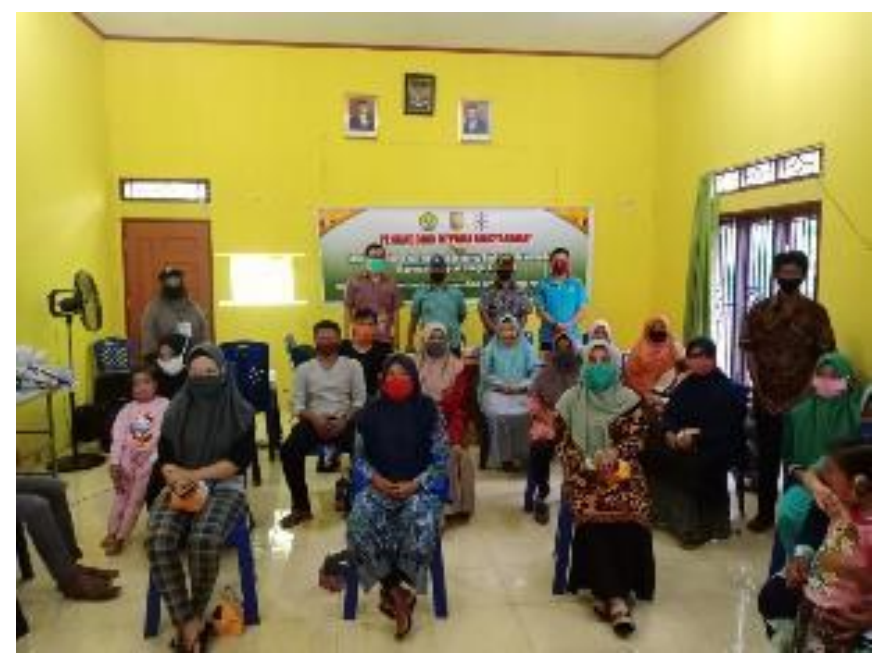

Gambar 2. Suasana Edukasi Covid-19 kepada Masyarakat Pulau Kedungdung

Kegiatan pengabdian pengabdian dilakukan pada hari Sabtu, 25 Juli 2020 di kantor desa Pulau Kedungdung. Peserta yang hadir berjumlah 30 orang. Adapun jalannya kegiatan pengabdian kepada masyarakat adalah sebagai berikut: 1. Penyuluhan tentang Situasi Terkini Covid-19. Kegiatan pertama adalah memberikan informasi tentang situasi terkini Covid-19 di Priovinsi Riau dan kabupaten Kuantan Singingi. Tujuan diberikan materi ini adalah untuk meningkatkan kewaspadaan masyarakat akan penyakit ini. Disini kami menyampaikan bahwa angka kejadian kasus Covid-19 terus meningkat di Provinsi Riau, bahkan di bulan Julli 2020, juga telah ditemukan kasus di Kota Taluk Kuantan, ibukota Kuantan Singigi. (Dinas Kesehatan | Kabupaten Kuantan Singingi, 2020) Belum ada kasus yang ditemukan di desa Pulau Kedungdung, namun tetap saja keadaan ini berisiko. 2. Penyuluhan Tentang Pencegahan Covid-19. Untuk mengoptimalkan materi 
edukasi yang diberikan, maka tim pengabdian memberikan penyuluhan. Materi diberikan secara runut dimulai dari pengenalan beberapa penyakit Covid-19 dan upaya pencegahannya. Disini kami menjelaskan bahwa penyebaran virus Covid-19-19 dari manusia ke manusia melalui droplet. Untuk itu semua pihak wajib melindungi diri sendiri dengan sering-seringlah mencuci tangan dengan sabun dan air selama 20 detik terutama setelah Anda berada di tempat umum, atau setelah meniup hidung, batuk, atau bersin. Jika sabun dan air tidak tersedia, gunakan pembersih tangan yang mengandung setidaknya $60 \%$ alkohol. Tutupi semua permukaan tangan Anda dan gosokkan semuanya sampai kering. Hindari menyentuh mata, hidung, dan mulut Anda dengan tangan yang tidak dicuci. Disini kami menyarakankan agar di depan kantor desa, masjid, dan warung disediakan tempat cuci tangan dan sabun.

Selain ini kami juga menjelaskan perlunya mengndari kontak dekat dengan orang yang sakit jika Covid19-19 menyebar di komunitas sekitar. Ini sangat penting bagi orang-orang yang berisiko lebih tinggi untuk sakit parah. Perlu dilakuan menjaga jarak lebih 1 meter dan menggunakan masker. Selain itu bersihkan dan disinfeksi permukaan yang sering disentuh setiap hari. Ini termasuk meja, gagang pintu, sakelar lampu, countertops, gagang, meja, telepon, keyboard, toilet, keran, dan bak cuci. Jika permukaannya kotor, bersihkan menggunakan deterjen atau sabun dan air sebelum disinfeksi.

Masyarakat sangat antusias mendengarkan penjelasan dari tim pengabdian. Melalui kegiatan ini diharapkan tidak hanya dapat dicegah penularan penyakit Covid-19 namun juga untuk peningkatan kualitas hidup masyarakat.(Suyanto, Geater and Chongsuvivatwong, 2019) Kegiatan pengabdian ini juga dibantu oleh petugas puskesmas Taluk Kuantan dan mahasiswa kukerta. Sebagai evaluasi kegiatan, beberapa peserta diberikan pertanyaan dan diminta untuk mennjawab pertayaan Hasilnya peserta dapat menjawab dan memahami materi yang diberikan. Sebagai tindak lanjut, para mahasiswa kukerta melakukan upaya penyediaan sarana cuci tangan dan pemantauan penggunaan masker. Selain itu, pihak puskesmas juga memberikan no telepon yang bias dihubungi jika masyarakat memiliki gejala yang mirip covid.

\section{KESIMPULAN}

Simpulan dari kegiatan yang sudah dilakukan di Desa Pulau Kedungdung adalah telah dilakukannya kegiatan sosialisasi tentang pencegahan dan pengendalian Covid-19 dan merekomendasikan untuk dibentuknya sarana untuk pengendalian penyakit Covid-19 seperti tempat cuci tangan di tempat umum. Melalui edukasi ini diharapkan dapat mengenali gejala awal Covid-19 dan melaporkannya kepada pihak desa dan puskesmas untuk ditindaklanjuti.

\section{UCAPAN TERIMA KASIH}

Terimakasih diucapkan kepada pihak Puskesmas Taluk Kuantan dan Kepala Desa Pulau Kedundung yang telah menfasilitasi terlaksannaya kegiatan ini.

\section{DAFTAR PUSTAKA}

Anon 2020. Dinas Kesehatan | Kabupaten Kuantan Singingi. [online] Available at: <https://dinkes.kuansing.go.id/> [Accessed 3 Oct. 2020].

Anon 2020. Riau - Wikipedia bahasa Indonesia, ensiklopedia bebas. [online] Available at: <https://id.wikipedia.org/wiki/Riau> [Accessed 3 Oct. 2020].

Anon 2020. Riau Tanggap Virus Corona | Pemprov Riau. [online] Available at: <https://corona.riau.go.id/> [Accessed 3 Oct. 2020].

Byass, P., 2020. Eco-epidemiological assessment of the COVID-19 epidemic in China, January-February 2020. [preprint] Public and Global Health. Available at: <http://medrxiv.org/lookup/doi/10.1101/2020.03.29.20046565> [Accessed 15 May 2020].

DAF, P.A., 2020. Situasi Terkini Perkembangan COVID-19 17 Maret $2020 »$ Info Infeksi Emerging Kementerian Kesehatan RI. Info Infeksi Emerging Kementerian Kesehatan RI. Available at: $<$ https://covid19.kemkes.go.id/situasi-infeksi-emerging/info-corona-virus/situasi-terkini-perkembangan-covid19-17-maret-2020/> [Accessed 3 Oct. 2020].

Djalante, R., Lassa, J., Setiamarga, D., Sudjatma, A., Indrawan, M., Haryanto, B., Mahfud, C., Sinapoy, M.S., Djalante, S., Rafliana, I., Gunawan, L.A., Surtiari, G.A.K. and Warsilah, H., 2020. Review and analysis of current responses to COVID-19 in Indonesia: Period of January to March 2020. Progress in Disaster Science, 6, 100091. 
Maryanti, E. and Lestari, E., 2020. Pendidikan kesehatan dalam rangka menuju panti asuhan bebas pedikulosis kapitis di Kecamatan Siak Hulu Kabupaten Kampar. Riau Journal of Empowerment, 3(2), pp.97-103.

Pan, A., Liu, L., Wang, C., Guo, H., Hao, X., Wang, Q., Huang, J., He, N., Yu, H., Lin, X., Wei, S. and Wu, T., 2020. Association of Public Health Interventions With the Epidemiology of the COVID-19 Outbreak in Wuhan, China. JAMA, 323(19), 1915.

Sampurna, R.H., 2020. Meningkatkan kualitas hidup sehat masyarakat Dayak melalui lokakarya Sekolah Sehat di Kabupaten Landak Kalimantan Barat. Riau Journal of Empowerment, 3(2), 117-126.

Sasmita, N.R., Ikhwan, M., Suyanto, S. and Chongsuvivatwong, V., 2020. Optimal control on a mathematical model to pattern the progression of coronavirus disease 2019 (COVID-19) in Indonesia. Global Health Research and Policy, [online] 5(1). Available at: <https://ghrp.biomedcentral.com/articles/10.1186/s41256-020-00163-2〉 [Accessed 3 Oct. 2020].

Suyanto, S., Geater, A. and Chongsuvivatwong, V., 2019. The Effect of Treatment during A Haze/Post-Haze Year on Subsequent Respiratory Morbidity Status among Successful Treatment Tuberculosis Cases. International Journal of Environmental Research and Public Health, 16(23), 4669.

Tan, J., 2005. An initial investigation of the association between the SARS outbreak and weather: with the view of the environmental temperature and its variation. Journal of Epidemiology \& Community Health, 59(3), 186-192. 